\title{
Keefektifan Model Pembelajaran Inkuiri Terbuka dan Learning Cycle dalam Meningkatkan Kualitas Proses dan Hasil Belajar Kimia Siswa Kelas X Sma Negeri 3 Bontang
}

\author{
Imam Solihin 1 \\ ${ }^{1}$ Pendidikan Kimia-Universitas Negeri Malang
}

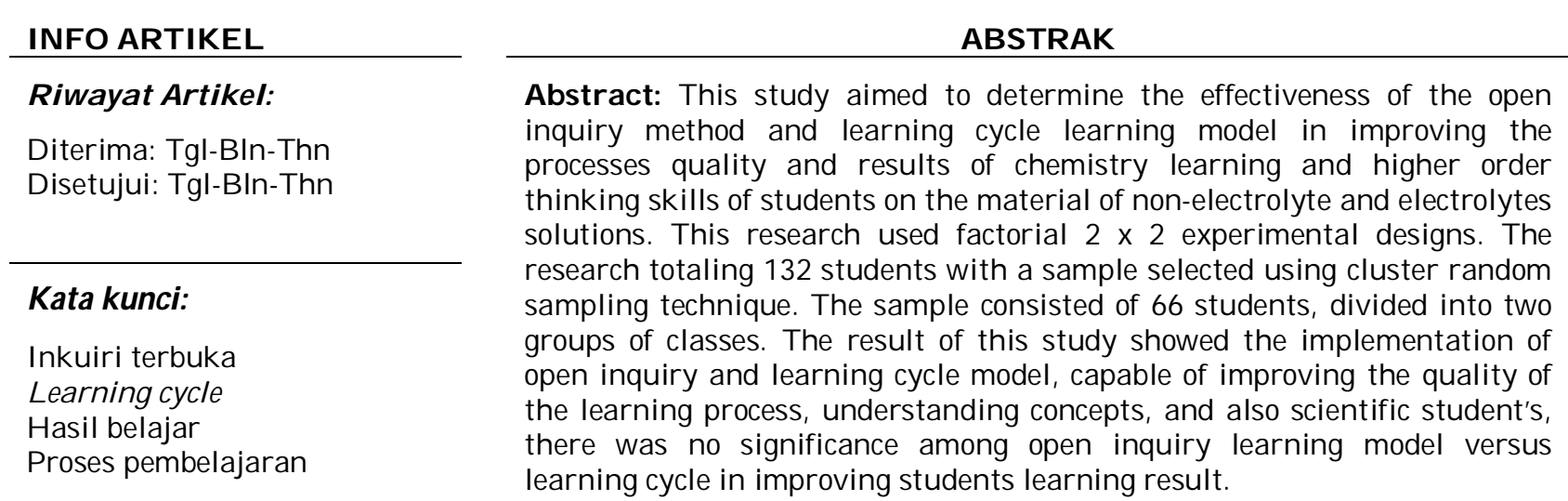

\begin{abstract}
Abstrak: Penelitian ini bertujuan untuk mengetahui keefektifan model inkuiri terbuka dan model pembelajaran $L C 5 E$ dalam meningkatkan kualitas proses dan hasil belajar kimia serta kemampuan berpikir tingkat tinggi siswa pada materi larutan elektrolit dan non-elektrolit. Penelitian ini mengunakan desain eksperimen faktorial $2 \times 2$. Populasi penelitian yang berjumlah 132 siswa dengan sampel yang dipilih menggunakan teknik cluster random sampling. Sampel terdiri atas 66 siswa yang terbagi dalam dua kelompok kelas. Hasil penelitian menunjukkan bahwa penerapan model inkuiri terbuka dan model pembelajaran $L C 5 E$, mampu meningkatkan kualitas proses pembelajaran, pemahaman konsep dan keterampilan proses serta sikap ilmiah siswa, tidak terdapat perbedaan keefektifan yang signifikan antara model inkuiri terbuka dan $L C 5 E$ dalam meningkatkan hasil belajar kimia siswa.
\end{abstract}

\footnotetext{
Alamat Korespondensi:

Imam Solihin

Pendidikan Kimia

Pascasarjana Universitas Negeri Malang

Jalan Semarang, 5 Malang 65154

E-mail: solihin.imam@yahoo.co.id
}

Tujuan pembelajaran kimia di SMA berdasarkan kurikulum 2006 antara lain adalah agar peserta didik: (1) memperoleh pengalaman dalam menerapkan metode ilmiah melalui percobaan atau eksperimen, (2) memahami konsep, prinsip, hukum, dan teori kimia serta saling keterkaitannya dan penerapanya untuk menyelesaikan masalah dalam kehidupan sehari-hari dan teknologi (Depdiknas, 2006). Pencapaian tujuan pembelajaran tersebut mengacu pada standar yang telah ditetapkan Pemerinta. Salah satu diantaranya menyatakan bahwa lulusan SMA mampu membangun dan menerapkan informasi dan pengetahuan secara 
logis, kritis, kreatif dan inovatif serta menunjukkan kemampuan berpikir logis, kritis, kreatif dan inovatif dalam pengambilan keputusan (BNSP, 2006).

Berdasarkan standar kompetensi lulusan satuan pendidikan salah satu kemampuan berpikir yang menjadi tujuan pembelajaran di SMA adalah kemampuan berpikir kritis. Kemampuan berpikir tingkat tinggi (high order thinking ability) merupakan bagian dari kemampuan berpikir kritis. Kemampuan tersebut sangat dibutuhkan pada pembelajaran kimia khususnya dan sebagai kecakapan hidup dalam era persaingan global saat ini.

Pembelajaran kemampuan berpikir tingkat tinggi di Indonesia khususnya di SMA Negeri 3 Bontang masih memiliki kendala, beberapa diantaranya: sistem penilaian prestasi siswa yang lebih banyak didasarkan melalui tes-tes yang sifatnya menguji kemampuan kognitif tingkat rendah (ingatan dan pemahaman), masih dominannya peran guru di sekolah sebagai sumber ilmu (teacher center oriented).

Salah satu usaha yang dapat dilaksanakan oleh guru untuk memperbaiki kondisi tersebut adalah dengan menciptakan pembelajaran yang kondusif melalui pembelajaran yang bersifat kontruktivistik. (Iskandar, 2009) menyatakan bahwa pembelajaran yang bersifat kontruktivistik memiliki ciri: (1) lebih memotivasi siswa dalam belajar sebab berpusat pada siswa, (2) mendorong siswa berfikir kritis, (3) memungkinkan penggunaan gaya belajar yang berbeda-beda sebagai akibat dari fokus perhatian kepada siswa secara individual, (4) mendorong siswa mencari informasi secara alami dan mandiri. Pembelajaran yang kontruktivistik dapat dilakukan guru dengan menggunakan metode-metode pembelajaran yang berorientasi kontruktivistik dan sesuai dengan karakteristik bidang studi yang diampu. Dewasa ini telah banyak dikembangkan metodemetode pembelajaran yang berlandaskan paradigma kontruktivistik, beberapa diantaranya adalah model pembelajaran inkuiri dan model pembelajaran learning cycle.

Pembelajaran inkuiri merupakan rangkaian kegiatan pembelajaran yang menekankan pada aspek perubahan, kebebasan berpikir secara kritis dan analitis untuk mencari dan menemukan sendiri jawaban dari suatu masalah yang dipertanyakan (Sadeh \& Zion, 2009). Dari beberapa hasil penelitian telah terbukti bahwa penerapan pembelajaran inkuiri mampu mengembangkan kemampuan berpikir kritis dan sikap ilmiah siswa. (Furtak, 2006) mengakui bahwa siswa yang belajar dalam setting inkuiri terbuka akan mampu mengaplikasikan metode dan proses berpikir ilmiah. (Krystyniak \& Heikkinen, 2007) menemukan bahwa siswa mampu meningkatkan kemampuan kerja ilmiah dan pemikiran yang lebih tinggi selama pembelajaran inkuiri terbuka.

Model pembelajaran learning cycle menurut (Lorsbach, 2002) memiliki 5 tahap pembelajaran, yaitu: tahap Engagement, Eksploration, Explanation, Elaboration, dan Evaluation. Tahap-tahap tersebut mengarahkan proses pembelajaran yang dapat melibatkan siswa dalam kegiatan belajar secara aktif, yang mendorong terjadinya proses asimilasi, akomodasi dan organisasi dalam struktur kognitif siswa. Beberapa penelitian yang menggunakan model pembelajaran $L C$ diantaranya dilakukan oleh (Budiasih \& Widarti, 2009; Maysara, 2006; Stuessy \& Metty, 2007) menunjukkan bahwa penerapan model pembelajaran $L C$ mampu meningkatkan kualitas proses pembelajaran, hasil belajar dan sikap ilmiah serta kemampuan berpikir siswa. Keefektifan model pembelajaran inkuiri terbuka dan learning cycle $5 E$ dalam meningkatkan kualitas proses dan hasil belajar kimia serta kemampuan berpikir tingkat tinggi siswa akan dibandingkan dalam penelitian ini.

Masalah yang akan dipecahkan dalam penelitian ini adalah (1) bagaimana perbedaan kualitas proses pembelajaran kimia siswa yang dibelajarkan dengan model pembelajaran inkuiri terbuka dibandingkan dengan siswa yang dibelajarkan dengan model pembelajaran $L C 5 E$ pada materi pokok larutan elektrolit dan nonelektrolit? (2) apakah terdapat perbedaan hasil belajar antara siswa yang dibelajarkan dengan model pembelajaran inkuiri terbuka dibandingkan siswa yang dibelajarkan dengan model pembelajaran $L C 5 E$ pada mata pelajaran kimia materi pokok larutan elektrolit dan nonelektrolit? (3) apakah terdapat perbedaan kemampuan berpikir tingkat tinggi antara siswa yang dibelajarkan dengan model pembelajaran inkuiri terbuka dibandingkan siswa yang dibelajarkan dengan model pembelajaran $L C 5 E$ pada mata pelajaran kimia materi pokok larutan elektrolit dan nonelektrolit? (4) Apakah terdapat perbedaan hasil belajar kimia secara signifikan pada siswa dengan kemampuan awal berbeda? (5) Apakah terdapat perbedaan kemampuan berpikir tingkat tinggi secara signifikan pada siswa dengan kemampuan awal berbeda? (6) Apakah terdapat interaksi antara model pembelajaran pembelajaran dan kemampuan awal siswa?

\section{METODE}

Penelitian ini menggunakan desain eksperimen faktorial $2 \times 2$. Makna dari desain tersebut adalah variabel pertama yaitu kemampuan awal siswa yang terdiri atas siswa yang memiliki kemampuan awal tinggi dan 
siswa yang memiliki kemampuan awal rendah. Variabel kedua adalah model pembelajaran yang terdiri atas model pembelajaran inkuiri terbuka dan model pembelajarn $L C 5 E$. Secara singkat rancangan penelitian yang digunakan dalam tahap uji coba lapangan dapat dilihat pada Tabel 1.

Populasi dari penelitian ini adalah siswa kelas X SMAN 3 Bontang semester 2 tahun pelajaran 2009/2010 yang terdiri dari 4 kelas dengan jumlah siswa 132 orang, dengan setiap kelas rata-rata diisi 33 siswa. Teknik sampling yang digunakan adalah cluster random sampling. Dari hasil pengundian diperoleh kelas X-C dengan jumlah siswa 33 siswa sebagai kelas $L C 5 E$ dan kelas X-D dengan jumlah siswa 33 siswa sebagai kelas inkuiri terbuka.

Teknik analisis data yang digunakan dalam penelitian ini terdiri dari (1) teknik analisis deskriptif yang digunakan untuk memperoleh kesimpulan tentang kualitas proses pembelajar melalui penerapan model pembelajaran inkuiri terbuka dan model pembelajaran $L C 5 E$, (2) analisa statistik menggunakan uji anakova untuk mengetahui perbedaan keefektifan penerapan model pembelajaran inkuiri terbuka dibandingkan penerapan model pembelajaran $L C 5 E$ pada taraf signifikansi $5 \%(\alpha=0,05)$.

Tabel 1. Desain Eksperimen Faktorial $2 \times 2$

\begin{tabular}{cccc}
\hline \multicolumn{2}{c}{$\begin{array}{c}\text { Variabel Bebas/ } \\
\text { Variabel Moderator }\end{array}$} & \multicolumn{2}{c}{ Model Pembelajaran } \\
Inkuiri Terbuka (Y1) & LC 5E (Y2) \\
\hline Kemampuan Akademik & Tinggi (X1) & X1Y1 & X1Y2 \\
& Rendah (X2) & X2Y1 & X2Y2 \\
\hline
\end{tabular}

Keterangan:

$\mathrm{X} 1 \mathrm{Y} 1$ : Hasil belajar dan high order thinking siswa berkemampuan awal tinggi dengan model pembelajaran inkuiri terbuka.

X1Y2 : Hasil belajar dan high order thinking siswa berkemampuan awal tinggi dengan model pembelajaran LC 5E.

X2Y1 : Hasil belajar dan higH order thinking siswa berkemampuan awal rendah dengan model pembelajaran inkuiri terbuka.

X2Y2 : Hasil belajar dan high order thinking siswa berkemampuan awal rendah dengan model pembelajaran LC 5E.

\section{HASIL}

\section{Deskripsi Data Kualitas Proses dan Keterlaksanaan Pembelajaran}

Proses pembelajaran materi larutan elektrolit dan non-elektrolit dalam penelitian ini dilakukan pada siswa SMAN 3 Bontang, kelas XC (menggunakan model pembelajaran inkuiri terbuka) dan XD (menggunakan model pembelajaran learning cycle 5E). Pembelajaran berlangsung selama enam kali pertemuan. Hasil penelitian tentang kualitas proses dan keterlaksanaan pembelajaran diperoleh dengan menggunakan lembar RTOP (Reformed Teaching Observation Protocol) dan lembar observasi keterlaksanaan pembelajaran. Hasil penelitian tentang kualitas proses dan keterlaksanaan pembelajaran pada kelas eksperimen dan kelas kontrol untuk setiap pertemuannya disajikan pada Tabel 2.

Tabel 2. Penilaian Kualitas Proses Pembelajaran Kelas Inkuiri dan Kelas $L C 5 E$

\begin{tabular}{|c|c|c|c|c|c|c|c|c|c|c|c|c|c|c|}
\hline \multirow[t]{3}{*}{ Item Yang Dinilai } & \multicolumn{7}{|c|}{ INKUIRI TERBUKA } & \multicolumn{7}{|c|}{$L C 5 E$} \\
\hline & \multicolumn{6}{|c|}{ Pertemuan } & \multicolumn{8}{|c|}{ Pertemuan } \\
\hline & $\begin{array}{l}\mathbf{I} \\
\overline{\mathbf{O}}\end{array}$ & $\begin{array}{l}\text { II } \\
\overline{\mathbf{O}}\end{array}$ & $\begin{array}{c}\text { III } \\
\overline{\mathbf{O}}\end{array}$ & $\begin{array}{c}\mathbf{I V} \\
\overline{\mathbf{O}}\end{array}$ & $\begin{array}{l}\mathbf{V} \\
\overline{\mathbf{O}}\end{array}$ & $\begin{array}{c}\text { VI } \\
\overline{\mathbf{O}}\end{array}$ & Rata-rata & $\begin{array}{l}\mathbf{I} \\
\overline{\mathbf{O}}\end{array}$ & $\begin{array}{l}\text { II } \\
\overline{\mathbf{O}}\end{array}$ & $\begin{array}{c}\text { III } \\
\overline{\mathbf{O}}\end{array}$ & $\begin{array}{c}\text { IV } \\
\overline{\mathbf{O}}\end{array}$ & $\begin{array}{l}\mathbf{V} \\
\overline{\mathbf{O}}\end{array}$ & $\begin{array}{c}\text { VI } \\
\overline{0}\end{array}$ & Rata-rata \\
\hline $1-5$ & 2.3 & 2.7 & 3.0 & 3.1 & 3.2 & 3.4 & 2.99 & 2.6 & 2.9 & 3.3 & 3.3 & 3.5 & 3.6 & 3.21 \\
\hline $6-10$ & 2.7 & 3 & 3.3 & 3.3 & 3.4 & 3.4 & 3.19 & 2.7 & 2.8 & 3.2 & 3.3 & 3.4 & 3.6 & 3.17 \\
\hline $11-15$ & 2.5 & 2.7 & 3.2 & 3.3 & 3.3 & 3.4 & 3.08 & 2.5 & 2.9 & 3.3 & 3.3 & 3.6 & 3.6 & 3.19 \\
\hline $16-20$ & 2.5 & 2.9 & 3.0 & 3.3 & 3.5 & 3.5 & 3.12 & 2.6 & 2.4 & 3.4 & 3.3 & 3.8 & 3.7 & 3.21 \\
\hline $21-25$ & 2.3 & 2.8 & 3.2 & 3.4 & 3.5 & 3.5 & 3.13 & 2.5 & 2.4 & 3.3 & 3.6 & 3.6 & 3.7 & 3.18 \\
\hline Rata-Rata & 2.5 & 2.8 & 3.1 & 3.3 & 3.4 & 3.4 & 3.09 & 2.6 & 2.7 & 3.3 & 3.4 & 3.6 & 3.6 & 3.19 \\
\hline
\end{tabular}

Sumber data: hasil pengamatan tiga observer pada enam kali pertemuan menggunakan RTOP

(Reformed Teaching Observation Protocol) 
Data penilaian kualitas proses pembelajaran materi larutan elektrolit dan non-elektrolit pada siswa kelas inkuiri terbuka dan kelas $L C 5 E$ diperoleh dari penilaian yang diberikan oleh tiga observer terhadap variabel yang muncul menggunakan lembar observasi RTOP. Variabel yang diamati terdiri dari: Desain Pembelajaran (item 1-5); Proporsional Pengetahuan (item 6-10); Prosedur Pengetahuan (11-15); Interaksi yang Komunikatif (16-20); Hubungan Siswa dan Guru (20-25). Dari Tabel 2 diketahui bahwa skor rata-rata untuk setiap variabel dalam enam kali pertemuan untuk pembelajaran menggunakan model inkuiri terbuka adalah 3,09 sedangkan untuk pembelajaran menggunakan model $L C 5 E$ mendapatkan skor 3,19. Kesimpulan dari data pada Tabel 2 menyatakan bahwa tidak terdapat perbedaan kualitas proses pembelajaran model inkuiri terbuka dan model pembelajaran $L C 5 E$. Kedua model pembelajaran mampu meningkatkan kualitas proses pembelajaran kimia kelas X SMA Negeri 3 Bontang pada materi larutan elektrolit dan non-elektrolit.

\section{Data Hasil Belajar Kimia Siswa}

Dalam penelitian ini data hasil belajar kimia siswa yang diperoleh meliputi: data hasil belajar ranah kognitif, afektif dan psikomotorik. Data-data tersebut secara ringkas ditampilkan dalam Tabel 3.

\begin{tabular}{ccccccc} 
Tabel 3. Ringkasan Data Hasil Penilaian Kognitif, Afektif dan Psikomotor Siswa. \\
\hline \multicolumn{3}{c}{ Inkuiri Terbuka } & \multicolumn{4}{c}{ LC E E } \\
Perihal & NK & NA & NP & NK & NA & NP \\
Kelas & & & & & & \\
\hline Nilai tertinggi & 96.8 & 87.5 & 93.3 & 94.8 & 87.2 & 90.5 \\
Nilai terendah & 40.0 & 68.6 & 61.9 & 44.0 & 67.7 & 61.9 \\
Rata-rata & 70.3 & 79.1 & 78.7 & 71.9 & 77.0 & 79.3 \\
Standar deviasi & 13.0 & 5.5 & 9.6 & 9.6 & 6.2 & 9.0 \\
\hline
\end{tabular}

NK = Nilai Kognitif; NA = Nilai Afektif; dan NP = Nilai Psikomotorik

Berdasarkan data pada Tabel 3 diketahui bahwa rata-rata nilai kognitif siswa yang dibelajarkan dengan model pembelajaran $L C 5 E$ lebih tinggi dibandingkan rata-rata nilai kognitif siswa yang dibelajarkan dengan model pembelajaran inkuiri terbuka, yaitu 71,9 : 70,3. Untuk aspek afektif, nilai rata-rata siswa yang dibelajarkan dengan model pembelajaran inkuiri terbuka lebih tinggi dibandingkan nilai rata-rata siswa yang dibelajarkan dengan model pembelajaran $L C 5 E$ yaitu 79,1 : 77, Sedangkan untuk aspek psikomotorik, nilai rata-rata kedua kelompok kelas adalah hampir sama, yaitu 78,7 untuk kelas inkuiri terbuka dan 79,3 untuk kelas $L C 5 E$.

Kesimpulan dari data pada Tabel 3 menyatakan bahwa tidak terdapat perbedaan kualitas hasil belajar antara siswa yang dibelajarkan dengan model pembelajaran inkuiri terbuka dan model pembelajaran $L C 5 E$. Secara umum hasil belajar siswa yang dibelajarkan dengan model pembelajaran inkuiri terbuka maupun siswa yang dibelajarkan dengan model pembelajaran $L C 5 E$ mengalami peningkatan jika dibandingkan dengan hasil belajar pada materi sebelumnya dengan menggunakan model pembelajaran konvensional.

\section{Deskripsi Kemampuan Berpikir Tingkat Tinggi (high order thinking ability)}

Kemampuan berpikir tingkat tinggi dalam penelitian ini terakomodasi dalam soal postes jenjang kemampuan C4, C5, dan C6 (analisis, sintesis dan evaluasi). Pembelajaran dengan model pembelajaran inkuiri terbuka dan model pembelajaran $L C 5 E$ secara teoritik mampu meningkatkan kemampuan berpikir tingkat tinggi siswa. Tabel 4 menunjukkan persentase siswa yang menjawab benar soal postes pada jenjang kemampuan C4-C5.

Hasil penelitian menunjukkan bahwa persentase siswa kelompok tinggi pada pembelajaran menggunakan model pembelajaran inkuiri terbuka mampu menjawab soal tes pada jenjang kemampuan C4-C6 lebih baik dibandingkan siswa kelompok tinggi pada model pembelajaran $L C 5 E$. Sebaliknya siswa kelompok rendah pada kelas yang dibelajarkan dengan model pembelajaran $L C 5 E$ memiliki persentase menjawab benar soal tes C4-C6 lebih baik dibandingkan siswa kelompok rendah dengan model pembelajaran inkuiri terbuka.

Data perbandingan rata-rata nilai kemampuan berpikir tingkat tinggi antara kelompok tinggi dan kelompok rendah pada model pembelajaran inkuiri terbuka dan model pembelajaran $L C 5 E$ ditunjukkan dalam Tabel 5. 
Tabel 4. Persentase Siswa Menjawab Benar Pada Jenjang Kemampuan C4-C6

\begin{tabular}{|c|c|c|c|c|c|}
\hline \multirow[t]{2}{*}{ No Soal } & \multirow[t]{2}{*}{$\begin{array}{l}\text { Jenjang } \\
\text { Kognitif }\end{array}$} & \multicolumn{2}{|c|}{$\begin{array}{c}\text { Inkuiri Terbuka } \\
\text { Kelompok }\end{array}$} & \multicolumn{2}{|c|}{$\begin{array}{c}L C 5 E \\
\text { Kelompok }\end{array}$} \\
\hline & & Tinggi & Rendah & Tinggi & Rendah \\
\hline $6,8,15,17,13,20$ & $\mathrm{C} 4$ & $86 \%$ & $57 \%$ & $83 \%$ & $67 \%$ \\
\hline $5,10,12,14,16$ & C5 & $77 \%$ & $45 \%$ & $67 \%$ & $64 \%$ \\
\hline 9,11 & C6 & $77 \%$ & $23 \%$ & $60 \%$ & $40 \%$ \\
\hline
\end{tabular}

Sumber data: skor postes materi larutan elektrolit dan non-elektrolit

Tabel 5. Nilai Rata-rata Kemampuan Berpikir Tingkat Tinggi C4-C6 (HOT)

\begin{tabular}{ccc}
\hline Kelompok Siswa & \multicolumn{2}{c}{ Nilai Rata-Rata Hot } \\
& Eksperimen & Kontrol \\
\hline Tinggi & 81 & 73 \\
Rendah & 47 & 62 \\
Rata-Rata & 64 & 67 \\
\hline
\end{tabular}

Kesimpulan dari data pada Tabel 4 \& 5 adalah: (1) model pembelajaran inkuiri terbuka lebih efektif diterapkan untuk meningkatkan kemampuan berpikir tingkat tinggi pada siswa yang memiliki kemampuan awal tinggi tetapi kurang efektif diterapkan pada siswa berkemampuan awal rendah, (2) model pembelajar-an $L C 5 E$ efektif diterapkan untuk meningkatkan kemampuan berpikir tingkat tinggi pada siswa yang memiliki kemampuan awal tinggi maupun siswa yang memiliki kemampuan awal rendah.

\section{Hasil Pengujian Hipotesis Data Hasil Belajar Kognitif}

Pengujian hipotesis dilakukan dengan melakukan analisis statistik menggunakan uji anakova pada taraf signifikasi 5\% $(\alpha=0,05)$. Ringkasan hasil analisis dipaparkan pada Tabel 6.

Tabel 6. Hasil Analisis Uji Anakova Terhadap Hasil Belajar Kognitif Siswa

\begin{tabular}{|c|c|c|c|c|c|c|}
\hline Source & $\begin{array}{l}\text { Type III Sum } \\
\text { of Squares }\end{array}$ & $\begin{array}{l}\mathbf{d} \\
\mathbf{f}\end{array}$ & $\begin{array}{c}\text { Mean } \\
\text { Square }\end{array}$ & $\mathbf{F}$ & $\begin{array}{l}\text { Si } \\
\text { g. }\end{array}$ & $\begin{array}{c}\text { Partial Eta } \\
\text { Squared }\end{array}$ \\
\hline Kategori & 102.817 & 1 & 102.817 & 2.120 & $\begin{array}{c}.15 \\
1\end{array}$ & .037 \\
\hline $\begin{array}{c}\text { Model } \\
\text { Pembelajaran }\end{array}$ & 32.937 & 1 & 32.937 & .679 & $\begin{array}{c}.41 \\
3\end{array}$ & .012 \\
\hline Kemampuan Awal & 1349.649 & 1 & 1349.649 & 27.833 & $\begin{array}{c}.00 \\
0\end{array}$ & .336 \\
\hline $\begin{array}{c}\text { Model* } \\
\text { Kemampuan }\end{array}$ & 648.079 & 1 & 648.079 & 13.365 & $\begin{array}{c}.00 \\
1\end{array}$ & .195 \\
\hline
\end{tabular}

Berdasarkan hasil uji statistik anakova, perbedaan keefektifan model pembelajaran inkuiri dan model pembelajaran $L C 5 E$ dalam meningkatkan kualitas hasil belajar kognitif siswa dapat diinterpretasikan sebagai berikut: (1) Variabel model pembelajaran memiliki nilai signifikasi 0,413 > alpha 0,05, dengan demikian hasil penelitian menerima hipotesis nihil $\left(\mathrm{H}_{0}\right)$ dan menyatakan bahwa tidak terdapat perbedaan hasil belajar kimia pada ranah kognitif antara kelompok siswa yang menggunakan model pembelajaran inkuiri terbuka dan model pembelajaran $L C$ 5E. (2) Variabel kemampuan awal memiliki nilai signifikasi 0,000 $<0,05$, dengan demikian hasil penelitian menolak hipotesis nihil $\left(\mathrm{H}_{0}\right)$ dan menyatakan bahwa terdapat perbedaan hasil belajar kimia pada ranah kognitif secara signifikan pada siswa dengan kemampuan awal berbeda. (3) Interaksi antara model pembelajaran dan kemampuan awal siswa memiliki signifikasi 0,001< alpha 0,05 , dengan demikian hasil penelitian menolak hipotesis nihil $\left(\mathrm{H}_{0}\right)$ dan menyatakan bahwa terdapat interaksi antara model pembelajaran dengan kemampuan awal siswa. 


\section{Hasil Pengujian Hipotesis Data High Order Thinking Ability}

Ringkasan hasil analisis data high order thinking ability dipaparkan pada Tabel 7. Berdasarkan hasil uji statistik anakova, perbedaan keefektifan model pembelajaran inkuiri dan model pembelajaran $L C 5 E$ dalam meningkatkan high order thinking ability siswa dapat diinterpretasikan sebagai berikut: (1) Variabel model pembelajaran memiliki nilai signifikasi $0,001<0,05$, dengan demikian hasil penelitian menolak hipotesis nihil $\left(\mathrm{H}_{0}\right)$ dan menyatakan bahwa terdapat perbedaan high order thinking ability antara kelompok siswa yang menggunakan model pembelajaran inkuiri terbuka dan model pembelajaran $L C$ 5E. (2) Variabel kemampuan awal memiliki nilai signifikasi $0,002<$ alpha 0,05 , dengan demikian penelitian menolak hipotesis nihil $\left(\mathrm{H}_{0}\right)$ dan menyatakan bahwa terdapat perbedaan high order thinking ability secara signifikan pada siswa dengan kemampuan awal berbeda. (3) Interaksi antara model pembelajaran dan kemampuan awal siswa terhadap high order thinking ability memiliki nilai signifikasi $0,001<$ alpha 0,05, dengan demikian hasil penelitian menolak hipotesis nihil $\left(\mathrm{H}_{0}\right)$ dan menyatakan bahwa terdapat interaksi antara model pembelajaran dengan kemampuan awal siswa terhadap.

Tabel 7. Hasil Analisis Uji Anakova high order thinking ability (Siswa Dependent Variable: high order thinking ability)

\begin{tabular}{ccccccc}
\hline Source & Type III Sum of Squares & Df & Mean Square & F & Sig. & Partial Eta Squared \\
\hline Kategori & 312,425 & 1 & 312,425 & 2,326 & 0,133 & 0,041 \\
Model Pembelajaran & 1795,017 & 1 & 1795,017 & 13,364 & 0,001 & 0,195 \\
Kemampuan Awal & 1439,881 & 1 & 1439,881 & 10,720 & 0,002 & 0,163 \\
Model * Kemampuan & 1583,512 & 1 & 1583,512 & 11,789 & 0,001 & 0,177 \\
\hline
\end{tabular}

\section{PEMBAHASAN}

\section{Kualitas Proses Pembelajaran Kimia}

Sesuai dengan hasil analisis data observasi secara deskriptif kuantitatif yang menyatakan bahwa tidak terdapat perbedaan kualitas proses pembelajaran antara siswa yang menggunakan model pembelajaran inkuiri terbuka dan siswa yang menggunakan model pembelajaran $L C 5 E$. Hasil penelitian tersebut menunjukkan bahwa ditinjau dari desain pembelajaran, isi pembelajaran, dan aplikasi pembelajaran menggunakan model pembelajaran inkuiri terbuka dan model pembelajaran $L C 5 E$ mampu meningkatkan aktifitas dan keterlibatan siswa dalam memperoleh pengetahuan.

Hasil penelitian ini menunjukkan bahwa pembelajaran menggunakan model pembelajaran inkuiri terbuka dan model pembelajaran $L C 5 E$ memiliki beberapa kelebihan, yaitu: 1) mengakomodasi pengetahuan yang telah dimiliki siswa sebelumnya, 2) memberikan kesempatan yang lebih besar bagi siswa dalam menentukan arah pembelajaran, 3) mengajak siswa untuk lebih aktif mancari, menentukan dan menggunakan berbagai cara alternatif yang lebih efektif dalam melakukan penyelidikan dan penemuan pengetahuan yang dibutuhkannya, 4) mengarahkan siswa untuk lebih aktif dalam menyampaikan pendapatnya dan memberikan peluang bagi tumbuhnya kepercayaan diri siswa atas kemampuan yang dimilikinya.

Hasil penelitian ini sesuai dengan pendapat (Sanjaya, 2006; Soetjipto, 1997) yang menyatakan bahwa keunggulan pembelajaran yang berbasis inkuiri adalah menekankan pada pengembangan aspek kognitif, afektif, dan psikomotor secara seimbang, sehingga pembelajaran menjadi lebih bermakna. Kebermaknaan tersebut berimplikasi pada hasil belajar yang dicapai siswa. Hasil penelitian ini mendukung hasil-hasil penelitian tentang penerapan model pembelajaran inkuiri terbuka dan model pembelajaran Learning Cycle yang dilakukan oleh: (1) (Sadeh \& Zion, 2009) yang menemukan bahwa pembelajaran inkuiri terbuka mampu meningkatkan pemahaman prosedural dan kemampuan inkuiri siswa, (2) (Sulistina, 2009) menyatakan bahwa kualitas proses pembelajaran menggunakan metoda inkuiri terbuka dan metoda inkuiri terbimbing, telah memungkinkan terjadinya peningkatan konstruksi pengetahuan dan keterampilan proses serta sikap sains siswa berlangsung dengan kategori baik, (3) (Iskandar, 2009) menemukan bahwa, model pembelajaran Learning Cycle dapat memperbaiki kualitas belajar siswa yang nampak pada hasil belajar dan partisipasi siswa, (4) (Budiasih \& Widarti, 2009) menyatakan bahwa model pembelajaran Learning Cycle mampu meningkatkan kualitas pembelajaran yang ditunjukkan dengan antusiasme, motivasi, dan aktivitas siswa meningkat selama proses pembelajaran. Hasil penelitian ini sekaligus mematahkan pendapat Rosadi (2006) yang menyatakan bahwa pembelajaran ilmu kimia di tingkat SMA dengan pendekatan inkuiri terbuka 
dipastikan tidak berhasil, karena siswa dipandang belum mampu khususnya dalam merumuskan masalah dan merencanakan eksperimen secara mandiri.

Dalam penelitian ini ditemukan, bahwa siswa yang dibelajarkan dengan model pembelajaran inkuiri terbuka khususnya yang memiliki kemampuan awal tinggi mampu menentukan masalah dan merencanakan penyelidikan untuk menyelesaikan masalah yang dibuatnya, serta mengambil keputusan terhadap hasil penyelidikan yang dilakukannya. Fase perumusan masalah dalam model pembelajaran inkuiri terbuka memberikan peluang bagi siswa untuk mengembangkan kemampuan ilmiahnya dalam melihat suatu topik. (Sanjaya, 2006) menyatakan bahwa siswa yang diberi kesempatan untuk merumuskan sendiri masalah yang akan dipelajari memiliki motivasi belajar yang tinggi. Fase ini merupakan fase yang paling menentukan keberhasilan proses pembelajaran menggunakan model pembelajaran inkuiri terbuka. Dibutuhkan perhatian dan perencanaan yang matang dari seorang guru agar siswa mampu merumuskan masalah dan mengerti tujuan apa yang ingin dicapai dari perumusan masalah tersebut. Masalah akan timbul manakala siswa tidak mampu merumuskan masalah dari topik-topik yang disediakan. Siswa akan mengalami keprustasian karena tidak mampu merumuskan masalah yang diinginkan hal tersebut akan mengakibatkan kegagalan pembelajaran dengan model pembelajaran inkuiri terbuka.

Dalam penelitian ini juga ditemukan bahwa melalui model pembelajaran $L C 5 E$ kemampuan berpikir dan sikap ilmiah siswa, baik yang memiliki kemampua awal tinggi maupun kemampuan awal rendah dapat ditingkatkan. Siswa mampu secara aktif melakukan eksplorasi terhadap literatur dan sumber belajar lain yang relevan untuk menemukan konsep dan membuktikan kebenaran konsep tersebut melalui kegiata eksperimen. Kemampuan tersebut dimungkinkan karena dalam proses inkuiri, siswa mendapat bimbingan secara terstruktur dari guru melalui pertanyaan-pertanyaan yang diberikan. Pertanyaan-pertanyaan pada model pembelajaran $L C 5 E$ mampu membangkitkan rasa ingin tahu siswa sehingga siswa terdorong untuk melakukan penyelidikan baik terhadap literatur dan sumber belajar yang relevan maupun melalui kegitan eksperimen.

Dalam penelitian ini permasalahan timbul diawal pertemuan, dimana siswa belum terbiasa menggunakan model pembelajaran inkuiri terbuka dan model pembelajaran $L C 5 E$. Khususnya pada penerapan model pembelajaran inkuiri terbuka, peneliti sangat kesulitan untuk memotivasi siswa berkemampuan awal rendah agar dapat bekerja secara mandiri dalam merumuskan masalah, membuat hipotesis dan merancang percobaan. Sebagian besar siswa berkemampuan awal rendah belum memahami topik dan tujuan pembelajaran materi larutan elektrolit dan nonelektrolit.

Ada dua solusi yang peneliti ambil untuk memperbaiki kondisi tersebut pada saat itu. Sosuli pertama adalah dengan memasukkan siswa-siswa berkemampuan tinggi kedalam kelompok yang beranggotakan siswa berkemampuan rendah. Harapan yang ingin dicapai dari solusi ini adalah terjadi interaksi sosial antara siswa berkemampuan rendah dengan siswa berkemampuan tinggi, serta menumbuh-kan sikap saling menghargai dan bekerjasama antara siswa. Solusi kedua adalah peneliti menyampaikan kembali tujuan pem-belajaran secara jelas dan rinci sehingga siswa memahami apa yang ingin dicapai dari pembelajaran materi larutan elektrolit dan non-elektrolit melalui model pem-belajaran inkuiri terbuka. Solusi ini sesuai dengan pendapat (Germann, Haskins, \& Auls, 1996) yang menyatakan bahwa tujuan pembelajaran dalam model pembelajaran inkuiri akan membantu siswa mengatasi kompleksitas penelitian ilmiah sehingga mereka mampu menggunakan model pembelajaran inkuiri terbuka secara mandiri pada saat mereka mampu.

\section{Perbedaan Hasil Belajar Siswa Pada Ranah Kognitif}

Hasil analisis data menunjukkan bahwa tidak terdapat perbedaan yang signifikan antara penerapan model pembelajaran inkuiri terbuka dan model pem-belajaran $L C 5 E$ dalam meningkatkan hasil belajar kognitif siswa. Hasil penelitian menunjukkan bahwa penerapan model pembelajaran inkuiri terbuka dan $L C 5 E$ mampu meningkatkan kualitas hasil belajar siswa. Hal tersebut dibuktikan dari peningkatan hasil belajar yang signifikan dibandingkan dengan hasil belajar ranah kognitif yang diperoleh siswa pada materi sebelumnya. Berdasarkan evaluasi hasil belajar siswa kelas X SMA Negeri Bontang tahun ajaran 2009/2010, sebanyak 75 siswa dari 75 dari 132 siswa (57\%) mendapatkan nilai dibawah SKBM yang ditetapkan 65 (pembelajaran menggunakan model konvensional). Setelah penelitian menggunakan model pembelajaran inkuiri terbuka dan model pembelajaran $L C 5 E$ pada materi larutan elektrolit dan non-elektrolit, tingkat ketuntasan meningkat menjadi $73,3 \%$ untuk siswa yang menggunakan model pembelajaran inkuiri terbuka dan $86,7 \%$ untuk siswa yang menggunakan model pembelajaran $L C 5 E$. 
Dari hasil penelitian diketahui bahwa hasil belajar siswa berkemampuan awal tinggi pada kelas model pembelajaran inkuiri terbuka lebih tinggi dibanding-kan hasil belajar siswa kelompok tinggi pada kelas model pembelajaran $L C 5 E$. Sebaliknya hasil belajar siswa kelompok rendah pada kelas model pembelajaran $L C 5 E$ lebih tinggi dibandingkan hasil belajar siswa kelompok rendah pada kelas model pembelajaran inkuiri terbuka. Hal tersebut menunjukkan adanya interaksi antara model pembelajaran yang digunakan dengan kemampuan awal siswa yang berbeda.

Hasil penelitian tersebut menunjukkan bahwa model pembelajaran inkuiri terbuka memberikan suasana belajar yang kondusif bagi siswa berkemampuan akademik tinggi yang kaya akan kreatifitas. Selain itu model pembelajaran inkuiri terbuka memberikan kesempatan yang luas bagi siswa untuk menunjukkan kemampuan dirinya. Hasil penelitian ini mendukung pendapat Bruner dalam (Amien, 1987) yang menyatakan bahwa pembelajaran model pembelajaran inkuiri memberikan kepuasan yang bersifat intrinsik dan situasi belajar yang lebih merangsang. Siswa yang memiliki kemampuan akademik tinggi akan merasa tertantang untuk mampu menggunakan kemampuan berpikirnya yang lebih tinggi. Kemampuan berpikir tersebut digunakan untuk menemukan masalah sekaligus jawaban atas masalah yang dibuatnya sendiri serta menemukan konsep dari proses inkuiri yang dilakukannya. Hasil penelitian ini sesuai dengan hasil temuan (Krystyniak \& Heikkinen, 2007) yang menemukan bahwa siswa akan menggunakan kemampuan proses sains dan pemikiran yang lebih tinggi selama proyek inkuiri terbuka.

Sebaliknya rendahnya hasil belajar siswa kelompok rendah pada kelas inkuiri terbuka disebabkan oleh karena siswa berkemampuan rendah sangat minim pengalaman dan pengetahuan yang dapat digunakan untuk menyesuaikan diri pada situasi yang sedang dihadapinya yang dalam teori Piaget disebut sebagai skema. Kurangnya pengalaman dan pengetahuan tersebut menyebapkan ketidakmampuan siswa untuk menumbuhkan dan menggunakan kemampuan berpikirnya dalam menemukan masalah, merumuskan hipotesis dan melakukan pengujian serta mengambil keputusan terhadap topik yang dihadapinya. Hal tersebut dapat dijelaskan dengan teori Piaget tentang kesetimbangan kognitif (cognitive equilibrium) sebagai berikut. Proses kesetimbangan kognitif siswa kelompok rendah pada kelas inkuiri terbuka mungkin belum tercapai secara maksimal, dimana dalam proses asimilasi siswa telah mampu menerima dan mamasukkan pengetahuan baru kedalam struktur kognitif mereka, namun siswa belum mampu merubah struktur kognitifnya secara maksimal dalam proses akomodasi. Sedangkan dalam pembelajaran dengan model pembelajaran $L C$, peran guru lebih dominan dalam memandu siswa untuk melakukan penyelidikan dalam usaha menemukan konsep materi yang sedang dibelajarkan. Sehingga siswa kelompok rendah yang dibelajarkan dengan model pembelajaran $L C 5 E$ mampu secara maksimal dalam melakukan proses asimilasi dan akomodasi secara setimbang.

\section{Kemampuan Berpikir Tingkat Tinggi (high order thinking ability)}

Hasil penelitian menunjukkan adanya peningkatan kamampuan berpikir tingkat tinggi siswa kelas X SMA Negeri 3 Bontang. Kemampuan berpikir tingkat tinggi merupakan bagian dari hasil belajar siswa ranah kognitif pada tingkat pemahaman yang lebih tinggi yaitu pada kemampuan menganalisis, mengevaluasi dan menciptakan. Menurut (Wardani, 2013) bahwa tingkatan kognitif C4, C5, dan C6 merupakan kategori high order thinking.

Hasil penelitian menyatakan bahwa terdapat perbedaan kemampuan berpikir tingkat tinggi antara kelompok siswa yang menggunakan model pembelajaran inkuiri terbuka dan model pembelajaran $L C 5 \mathrm{E}$. Hal tersebut ditunjukkan dari rerata skor kemampuan berpikir tingkat tinggi siswa kelompok tinggi yang dibelajarkan dengan model pembelajaran inkuiri terbuka lebih tinggi dibandingkan siswa kelompok tinggi yang dibelajarkan dengan model pembelajaran $L C 5 E$, yaitu $84: 78$. Sedangkan skor yang diperoleh siswa kelompok rendah yang dibelajarkan dengan model pembelajaran inkuiri terbuka lebih rendah dibandingkan dengan skor yang diperoleh siswa kelompok rendah yang dibelajarkan dengan model pembelajaran $L C 5 E$, yaitu 59 untuk model pembelajaran inkuiri terbuka dan 66 untuk model pembelajaran $L C 5 E$.

Penerimaan hipotesis dan pencapaian skor rata-rata kemampuan berpikir tingkat tinggi tersebut menjelaskan bahwa pembelajaran yang didesain menggunakan model pembelajaran inkuiri terbuka lebih efektif jika diterapkan pada kelas dengan siswa berkemampuan akademik tinggi dibandingkan jika diterapkan pada siswa yang berkemampuan akademik rendah. Sebaliknya model pembelajaran $L C 5 E$ dapat diterapkan secara efektif baik untuk siswa berkemam-puan awal tinggi maupun berkemampuan awal rendah. Hal tersebut dimungkinkan karena untuk dapat merumuskan suatu masalah dari suatu topik, dibutuhkan 
kemampuan analisis terhadap fakta yang ada disekitarnya. Siswa yang belum terbiasa menggunakan dan meningkatkan kemampuan analisis akan mengalami kegagalan pada fase pertama tersebut, hal ini berakibat pada keprustasian siswa. Hasil penelitian ini menjawab apa yang diungkapkan oleh (Chin \& Chia, 2004) yang menyatakan bahwa model pembelajaran inkuiri terbuka membutuhkan kemampuan berpikir tinggi, dan sebuah komponen penting dalam menerapkan model pembelajaran inkuiri terbuka adalah kemampuan guru untuk memotivasi siswanya untuk menanyakan berbagai pertanyaan yang akan mengarah kepada penelitian mereka sendiri.

Hasil penelitian ini menunjukkan bahwa kemampuan berpikir tingkat tinggi tersebut harus dibina secara berlahan dan membutuhkan bimbingan dari seorang guru. Bimbingan yang dimaksud dapat berupa pertanyaan-pertanyaan yang mengarahkan pada siswa untuk dapat meningkatkan kemampuan analisis dari siswa. Pertanyaan-pertanyaan yang diberikan guru akan membantu siswa dalam mengembangkan kemampuan berpikir tingkat tinggi. Dengan demikian metode pembelajaran inkuiri terbimbing yang dalam hal ini diterapkan melalui model pembelajaran $L C 5 E$ akan lebih mampu mengembangkan kemampuan berpikir tingkat tinggi siswa, khususnya siswa dengan kemampuan awal rendah. Hasil penelitian ini mendukung pernyataan (Dimyati \& Mudjiono, 2002) bahwa tujuan utama pendekatan inkuri yaitu mengembangkan kemampuan intelektual, berpikir kritis, dan kemampuan dalam memecahkan masalah secara ilmiah.

Pernyataan tersebut didukung oleh pernyataan (Susilo, 2007) yang menyatakan bahwa dalam pembelajaran konstruktivistik guru dituntut untuk menggunakan pertanyaan yang baik, baik tingkat rendah maupun tingkat tinggi. Pertanyaan yang diajukan oleh guru harus digunakan dengan tepat, karena melalui pertanyaan siswa dapat terlatih untuk berpikir pada tingkat yang lebih tinggi. Pernyataan tersebut juga sesuai dengan pernyataan (Corebima, 2006), bahwa cara yang paling mudah untuk menantang pola pikir high order thinking adalah dengan pertanyaan. Pertanyaan yang runtut dan terkait dengan kehidupan sehari-hari dapat membantu siswa untuk memahami konsep secara runtut dan membantu siswa untuk membentuk sendiri pengetahuannya.

Hasil penelitian ini mendukung hasil-hasil penelitian tentang penerapan model pembelajaran inkuiri terbuka dan model pembelajaran learning cycle yang dilakukan oleh. (1) (Furtak, 2006) mengakui bahwa siswa yang belajar dalam setting inkuiri terbuka akan mampu mengaplikasikan model pembelajaran dan proses berpikir ilmiah, (2) (Krystyniak \& Heikkinen, 2007) menemukan bahwa siswa mampu meningkatkan kemampuan kerja ilmiah dan pemikiran yang lebih tinggi selama pembelajaran inkuiri terbuka, (3) dilakukan (Stuessy \& Metty, 2007) menunjukkan bahwa penerapan model pembelajaran LC mampu mening-katkan kualitas proses pembelajaran dalam kelas dan hasil belajar serta kemam-puan laboratorium siswa, (4) (Maysara, 2006), yang menyatakan bahwa model pembelajaran LC 3 fase dan 5 fase dapat meningkatkan prestasi belajar siswa pada materi pokok laju reaksi.

Hasil penelitian ini memberikan informasi tentang kelebihan penerapan model pembelajaran inkuiri terbuka dan model pembelajaran $L C 5 E$ yaitu diantaranya dapat meningkatkan kualitas proses dan hasil belajar siswa serta kemampuan berpikir tingkat tinggi siswa, mampu meningkatkan motivasi belajar, membantu mengurangi rasa cemas terhadap kegagalan mengikuti proses pem-belajaran, memberikan kesempatan pada siswa untuk mencapai pemahaman yang lebih luas dan menganalisis secara lebih mendalam tentang suatu topik, memberi kesempatan pada siswa untuk mengembangkan sikap kreatif, bertanggung jawab dan mandiri.

\section{Interaksi Antara Model Pembelajaran dan Kemampuan Awal Siswa}

Dari hasil uji anakova diketahui bahwa terdapat interaksi yang signifikan antara model pembelajaran dengan kemampuan awal siswa terhadap perbedaan hasil belajar kognitif dan kemampuan berpikir tingkat tinggi. Hasil analisis tersebut menjelaskan bahwa keberhasilan penerapan model pembelajaran untuk meningkatkan hasil belajar siswa juga dipengaruhi oleh variabel lain yaitu kemampuan awal (kemampuan akademik) siswa. Hasil analisi tersebut menjelaskan bahwa model pembelajaran inkuiri terbuka akan lebih efektif jika digunakan pada siswa yang memiliki kemampuan awal tinggi tetapi kurang efektif jika diterapkan pada siswa berkemampuan awal rendah. Hasil analisi tersebut juga menjelaskan bahwa model pembelajaran $L C 5 E$ dapat diterapkan pada siswa berkemampuan awal tinggi maupun siswa berkemampuan awal rendah.

Hasil penelitian ini memberikan informasi yang sangat penting bagi kita, bahwa pemilihan model pembelajaran akan memberikan dampak yang positif jika pemilihan tersebut dilakukan dengan 
mempertimbangkan faktor-faktor lain diantaranya kemampuan awal siswa. Tidak semua model pembelajaran baru dapat diterapkan pada peserta didik dan memberikan hasil yang baik.

\section{Permasalahan yang Dihadapi}

Selain kelebihan-kelebihan penerapan model pembelajaran inkuiri terbuka dan model pembelajaran $L C 5 E$ yang peneliti temukan selama penelitian, penelitian ini juga menunjukkan kekurangan-kekurangan dan kendala-kendala penerapan model pembelajaran inkuiri terbuka dan model pembelajaran $L C 5 E$. Kendalakendala tersebut diantaranya membutuhkan lebih banyak waktu bagi siswa untuk menjalani setiap tahapan pembelajaran maupun untuk menyelesaikan tugas-tugas yang diberikan, menyita lebih banyak waktu bagi pendidik, khususnya untuk membangkitkan, mengkondisi-kan pembelajaran dan melakukan asesmen autentik, terdapat kesenjangan antara siswa berkemampuan rendah dan siswa berkemampuan tinggi dalam hal aktifitas pembelajaran dan pencapaian hasil belajar. Dibutuhkan energi dan perhatian ekstra untuk mengendalikan dan menjaga ritme pembelajaran.

\section{Temuan Penelitian}

Berdasarkan hasil penelitian dan pembahasan dapat dirumuskan temuan penting dari penelitian ini adalah sebagai berikut: 1) Model pembelajaran inkuiri terbuka hanya akan efektif jika diterapkan untuk meningkatkan kualitas proses pembelajaran dan hasil belajar kimia serta kemampuan berpikir tingkat tinggi, pada siswa yang memiliki kemampuan akademik tinggi, tetapi kurang efektif bahkan kontra produktif jika diterapkan pada siswa yang memiliki kemampuan akademik rendah. 2) Model pembelajaran learning Cycle 5 fase efektif untuk meningkatkan kualitas proses pembelajaran dan hasil belajar kimia serta kemampuan berpikir tingkat tinggi pada siswa yang berkemampuan akademik tinggi maupun berkemampuan akademik rendah. 3) Model pembelajaran learning Cycle 5 fase ataupun model-model pembelajaran lain yang berbasis inkuiri pada tingkatan yang lebih rendah (inkuiri terbimbing) lebih efektif diterapkan untuk meningkatkan kualitas proses pembelajaran dan hasil belajar kimia serta kemampuan berpikir tingkat tinggi siswa pada kelas dengan siswa yang memiliki kemampuan akademik bervariatif (kelas heterogen).

\section{SIMPULAN DAN SARAN}

\section{Simpulan}

Berdasarkan hasil penelitian diperoleh kesimpulan, penerapan model pembelajaran inkuiri terbuka dan model pembelajaran $L C 5 E$ memberikan perbedaan keefektifan yang signifikan terhadap peningkatan kualitas proses pembelajaran. Penerapan model pembelajaran inkuiri terbuka dan model pembelajaran $L C 5 E$ memiliki keefektifan yang sama dalam meningkatkan hasil belajar kognitif siswa kelas X SMA Negeri 3 Bontang pada materi pokok larutan elektrolit dan nonelektrolit. Terdapat perbedaan keefektifan penerapan model pembelajaran inkuiri terbuka dan model pembelajaran $L C 5 E$ dalam meningkatkan kemampuan berpikir tingkat tinggi (high order thinking ability) siswa kelas X SMA Negeri 3 Bontang. Terdapat interaksi antara penerapan model pembelajaran dengan kemampuan awal siswa dalam meningkatkan hasil belajar kognitif dan kemampuan berpikir tingkat tinggi (high order thinking ability) siswa pada materi pokok larutan elektrolit dan nonelektrolit.

Model pembelajaran inkuiri terbuka hanya akan efektif jika diterapkan untuk meningkatkan kualitas proses pembelajaran dan hasil belajar kimia serta kemampuan berpikir tingkat tinggi, pada siswa yang memiliki kemampuan akademik tinggi, tetapi kurang efektif bahkan kontra produktif jika diterapkan pada siswa yang memiliki kemampuan akademik rendah. Penerapan model pembelajaran learning Cycle $5 E$ efektif untuk meningkatkan kualitas proses pembelajaran dan hasil belajar kimia serta kemampuan berpikir tingkat tinggi pada siswa yang berkemampuan awal tinggi maupun berkemampuan awal rendah.

\section{Saran}

Metode pembelajaran inkuiri terbuka dan model pembelajaran $L C 5 E$ sangat tepat diterapkan untuk meningkatkan hasil belajar siswa dan kemampuan berpikir tingkat tinggi siswa baik yang memiliki kemampuan awal tinggi maupun rendah pada pembelajaran bidang studi dalam rumpun IPA khususnya kimia, karena pembelajaran ini mampu meningkatkan kualitas proses pembelajaran sehingga siswa dapat belajar dengan lebih bermakna. 
Penerapan pembelajaran inkuiri terbuka akan lebih efektif jika diterapkan pada siswa yang memiliki kemampuan awal tinggi dan diterapkan secara kontinyu, sehingga siswa terbiasa untuk bekerja secara mandiri dalam memperoleh pengetahuannya. Penilaian pembelajaran siswa pada metode inkuiri terbuka dan model $L C 5 E$ hendaknya dilakukan secara utuh, kontinyu dan melibatkan aspek penilaian autentik pada setiap fasenya sehingga perkembangan dan permasalahan yang dihadapi siswa dapat dimonitor dan diperbaiki sejak dini, untuk memperoleh hasil pembelajaran yang maksimal. Pemberdayaan kemampuan berpikir siswa yang memiliki kemampuan awal berbeda lebih efektif jika menggunakan model pembelajaran $L C 5 E$ dibandingkan menggunakan model pembelajaran inkuiri terbuka.

Penelitian tentang penerapan model pembelajaran inkuiri terbuka dan $L C 5 E$ pada tingkat SMA, masih perlu dilakukan dengan variabel penelitian yang lebih beragam dalam upaya peningkatan kualitas pembelajaran di Indonesia.

\section{DAFTAR RUJUKAN}

Amien, M. (1987). Mengajarkan Ilmu Pengetahuan Alam (IPA) dengan menggunakan metode "discovery" dan "inquiry." Jakarta: Depdikbud.

BNSP. (2006). Panduan Penyusunan Kurikulum Tingkat Satuan Pendidikan Jenjang Pendidikan Dasar dan Menengah. Jakarta.

Budiasih, E., \& Widarti, H. R. (2009). Penerapan Pendekatan Daur Belajar (Learning Cycle) dalam Pembelajaran Matakuliah Praktikum Kimia Analisis Instrumentasi. Jurnal Pendidikan Dan Pembelajaran (JPP), 11(1).

Chin, C., \& Chia, L. G. (2004). Problem-based learning: Using students' questions to drive knowledge construction. Science Education, 88(5), 707-727.

Corebima, A. D. (2006). Pembelajaran biologi yang memberdayakan kemampuan berpikir siswa. In Makalah disajikan pada Pelatihan Strategi Metakognitif pada Pembelajaran Biologi untuk Guru-guru Biologi SMA (Vol. 23). Palangkaraya.

Depdiknas. (2006). Kurikulum 2006 Standar Kompetensi Mata Pelajaran Kimia Sekolah Menengah Atas dan Madrasyah Aliyah. Jakarta.

Dimyati, D., \& Mudjiono, M. (2002). Belajar dan Pembelajaran. Jakarta.

Furtak, E. M. (2006). The problem with answers: An exploration of guided scientific inquiry teaching. Science Education, 90(3), 453-467.

Germann, P. J., Haskins, S., \& Auls, S. (1996). Analysis of nine high school biology laboratory manuals: Promoting scientific inquiry. Journal of Research in Science Teaching: The Official Journal of the National Association for Research in Science Teaching, 33(5), 475-499.

Iskandar, S. M. (2009). Penerapan konstruktivisme dalam pembelajaran kimia di SMU. Media Komunikasi Kimia, 5(2).

Krystyniak, R. A., \& Heikkinen, H. W. (2007). Analysis of verbal interactions during an extended, open-inquiry general chemistry laboratory investigation. Journal of Research in Science Teaching: The Official Journal of the National Association for Research in Science Teaching, 44(8), 1160-1186.

Lorsbach, A. W. (2002). The learning cycle as a tool for planning science instruction.

Maysara, M. (2006). Keefektifan Model Pembelajaran Learning Cycle untuk Meningkatkan Prestasi Belajar Siswa Terhadap Konsep Laju Reaksi pada Siswa. Universitas Negeri Malang.

Sadeh, I., \& Zion, M. (2009). The development of dynamic inquiry performances within an open inquiry setting: A comparison to guided inquiry setting. Journal of Research in Science Teaching: The Official Journal of the National Association for Research in Science Teaching, 46(10), 1137-1160.

Sanjaya, W. (2006). Strategi pembelajaran berorientasi standar proses pendidikan. Jakarta: kencana.

Soetjipto, B. E. (1997). Penerapan Strategi Pengajaran Inkuiri untuk Meningkatkan CBSA di Sekolah. Jurnal Sumber Belajar, 4(November), 36-49.

Stuessy, C. L., \& Metty, J. S. (2007). The learning research cycle: Bridging research and practice. Journal of Science Teacher Education, 18(5), 725-750.

Sulistina, O. (2009). Keefektifan Penggunaan Metoda Pembelajaran Inkuiri Terbuka dan Inkuiri Terbimbing dalam Meningkatkan Proses Pembelajaran dan Hasil Belajar Kimia Siswa SMA Laboratorium Malang Kelas X. Universitas Negeri Malang.

Susilo, H. (2007). Pengembangan Kemampuan Berfikir dan Assessment Dalam Strategi Kooperatif. Makalah Disajikan Dalam Pelatihan Pengembangan Asesmen Autentik Dan Kemampuan Berpikir Serta.

Wardani, I. G. (2013). Berpikir Kritis dan Kreatif Terapannya dalam Pembelajaran. Sekolah Dasar: Kajian Teori Dan Praktik Pendidikan, 15(2). 